\title{
CEO EDUCATION, FINANCIAL DECISION AND FIRM PERFORMANCE
}

\author{
Rahmat Setiawan \& Lila Gestanti \\ Faculty of Economic and Business, Universitas Airlangga \\ E-mail: rahmatsetiawan@feb.unair.ac.id \& lila.gestanti-2016@feb.unair.ac.id
}

\begin{abstract}
Many previous studies have shown that the number of CEOs holds MBA is still low and less dominating. We analyze the effect of CEOs with MBA degree on funding decision, investment decision and firm performance. Using 38 manufacturing companies that listed on Indonesia stock exchange during 2010-2017 analyzed with multiple linear regression. We find that CEOs with MBA degree significantly have lower interest-bearing debt, higher capital expenditure and higher return on asset than companies with non-MBA CEOs. These research results provide information to shareholders and management of manufacturing companies to consider and provide equal opportunities to hire MM-MBA CEOs.
\end{abstract}

Keywords: CEO education, funding decision, investment decision, return on assets JEL Classification: G40, G41, G32

\begin{abstract}
ABSTRAK
Penelitian-penelitian sebelumnya telah menunjukkan bahwa jumlah CEO yang memegang MBA masih rendah dan kurang mendominasi. Penelitian ini menganalisis pengaruh CEO dengan gelar MBA pada keputusan pendanaan, keputusan investasi dan kinerja perusahaan. Penelitian dilakukan pada 38 perusahaan manufaktur yang terdaftar di bursa efek Indonesia selama 2010-2017 kemudian dianalisis dengan regresi linier berganda. Kami menemukan bahwa CEO dengan gelar MBA secara signifikan memiliki utang berbunga rendah, belanja modal yang lebih tinggi, dan pengembalian aset yang lebih tinggi daripada perusahaan dengan CEO non-MBA. Hasil penelitian ini memberikan informasi kepada pemegang saham dan manajemen perusahaan manufaktur untuk mempertimbangkan dan memberikan kesempatan yang sama untuk merekrut CEO MMMBA.
\end{abstract}

Kata kunci: Pendidikan CEO, keputusan pendanaan, keputusan investasi, laba atas asset Klasifikasi JEL: G40, G41, G32 


\section{Rahmat Setiawan \\ Lila Gestanti}

\section{INTRODUCTION}

Indonesia as one of the emerging markets offers attractive investments. The characteristics of emerging market countries tend to offer higher returns and risks than developed countries. After choosing Indonesia as an investment destination country, then choosing the right industry. The biggest industry in Indonesia is the manufacturing industry. Based on UN Statistic Division that published on Indonesian ministry of industry's website (2016), this industry can contribute $22 \%$ of Indonesia's GDP in 2016. This portion is higher than the average that surveyed by UN Statistic Division in fifteen countries. After we choosing countries and industries, then choosing which companies to invest. Many research results shows that CEO significantly affects corporate decision making and performance.

Which characteristics define a good CEO for the company? King et al. (2016) stated educational contains information about CEO quality and the latent ability of CEO. King et al. (2016) find that master degree more significantly affects firm performance than another degree like undergraduate and doctoral.

The phenomenon is many previous studies have shown that the number of CEOs holds MBA is still low and less dominating. Beber and Fabbri (2012) show during 1996-2001for non-financial companies of the S\&P 200: Index of December 2001, there were only $42.9 \%$ of MBA CEOs, King et al. (2016) show during 1992 to 2011 on publicly-listed US banks are only under $40 \%$ of the sample, in Korkeamaki et al. (2017) study show only $20.82 \%$ CEOs of the non-financial firms listed on the Helsinki Stock Exchange period 2002 to 2005 hold MBA. In this study also shows the number of CEOs with MBA education is still low and less dominating (24.7\%). How MBA CEOs manage the company, take a decision and its performance, so the numbers of MBA CEOs are still low.

Many evidence show CEOs with MBA degree will choose more aggressive strategies, but previous research didn't show clearly how CEOs with MBA made a financial decision until how the result (funding decision, investment decision until performance result). Nguyen et al. (2015) stated that there is no clear empirical evidence suggesting that MBA executives outperform non-MBA ones. Some previous researches see Tobin $Q$ to asses CEO with MBA performance (Bhagat et al., 2010), Custódio \& Metzger, 2014, Rossi et al., 2017). Tobin Q show the market's perspective, but Return on Asset can show the company's ability to generate profit as a result of how efficiently decision making and management are. ROA was chosen in this study because ROA as a result of operational performance is the final result of investment policy (model analysis 2) and funding policy (model analysis 1). 
This paper using 38 manufacturing companies listed on Indonesia stock exchange during 2010-2017. The number of companies in the Indonesian manufacturing industry has the highest number of companies, thus the competitive level between companies will be higher. Some previous studies show this characteristics (master business CEO) will assist in managing the company, thus can win competition in this industry. In Indonesia, there are another title equivalent to MBA (master of administration business) such as Master Management (MM). In order to add a sample of the number of CEOs with characteristics that have a master's business education, we also use CEOs with MM degrees. Thus, this study aims to investigate the effect of the MBA, MM CEO on funding decision (interest-bearing debt), investment decision (capital expenditure), and firm performance (ROA) which is controlled by firm size, and firm age using multiple linear regressions.

This research will be very useful, because it can provide more complete information about how MBA CEOs manage manufacturing companies from funding, investing decision to the final result in the form of operational performance (Return on Assets). This research will contribute to theory, show how relevant theory (behavioral finance theory) in Indonesia evidence for the researcher. Furthermore, this paper gives empirical evidence of how CEOs hold MM-MBA in Indonesia manufacturing companies takes decision, performance, which can be valuable information for shareholder, management manufacturing companies.

\section{LITERATURE REVIEW}

\section{Behavioral Finance Theory and MM-MBA CEO (Chief Executive Officer)}

The behavior of MM-MBA CEOs, non-MM CEOs, and non-MBA CEOs are identified as having different behaviors. Bhagat et al. (2010) and King et al. (2016) agreed that education is described as a critical factor in selecting the CEO, as it is a signal of CEO quality. MM-MBA CEOs have learned more about how to manage companies than non-MM- non MBA. Some research results show that this degree has an impact in business decision making up to performance results and maybe not rational in managing a company. According to Bodie et al. (2010: 382), this irrational behavior can arise because of two main reasons, there are bias and errors in processing information. In behavioral finance theory, CEOs with MM-MBA education will overconfidence, an error in processing information because they feel they have better education (better than average behavior). That's behavior make their tolerances to risk is higher and tend to speculate (Beber \& Fabbri, 2012). King et al. (2016); Custódio \& Meztger, 2014) show that CEOs with MBA education have more aggressive strategies, such as making a riskier decision and more innovative decisions. 


\section{Rahmat Setiawan \\ Lila Gestanti}

\section{Firm Characteristic}

This paper using two control variables. There are the firm size and firm age. Firm size shows the size of the company's wealth. The larger the firm size means the more wealthy and the greater the company's capabilities. According to Ross et al. (2010: 916), large companies have an economy of scale, which is the benefit of decreasing production costs per unit as production levels increase. Firm age shows how long the company has established until the year $t$ research. The company's age can control the life cycle stage of the company (Faccio et al., 2016). Mature companies tend to have the more free cash flow (Ross et al., 2010: 643).

\section{Master CEO and Interest-bearing debt}

Korkeamaki (2017) show companies led by MBA CEOs use higher leverage than CEO with no MBA degree. CEOs that hold MBA degree speculate more (Beber \& Fabbri, 2012). Korkeamaki (2017) explains that because CEOs with MBA degrees tend to be overconfident (better than average behavior) in accordance with Hackbart's (2008) study of overconfident managers use financial leverage more aggressively.

Frank and Goyal (2007) show that CEOs with MBA education can adjust capital structure more quickly to their optimum level. CEOs with higher education levels have more knowledge, understand the benefits of debt and can formulate the optimal level of debt. According to Custódio and Metzger (2014), CEOs with higher education will provide credibility. The Higher CEO education, the CEO's more sophisticated managing financial decision. When MM-MBA CEOs are having higher credibility as a borrower, then debt capacity of companies with MM-MBA CEOs will increase. Furthermore, MM-MBA CEOs will take that debt capacity because they are motivated by high compensation. MBA CEOs tend to get higher compensation than non-MBA CEOs (King et al., 2016).

\section{$H_{1}$ : Education CEO positively significant affects interest-bearing debt}

\section{Master CEO and Capital Expenditure}

The results of previous studies show that companies led by CEO with MBA degree tend to have higher investment than companies led by non-MBA CEOs. The higher the CEO's education, means the more sophisticated (Custódio \& Metzger, 2014) and the greater the CEO's skill in managing investments. This is because of they able to read conditions and opportunities correctly. That makes MBA CEO dare to invest more because they understand the situations. MBA degree can also make CEOs become overconfidence because they think they are better than average. Overconfidence behaviors lead CEO to become more aggressive in investment and speculate more (Beber \& Fabbri, 2012). In addition, high risk taking by increasing investment is motivated by higher compensation. MBA CEOs tend to get 
higher compensation because they have higher education (Lam et al., 2014; Graham et al., 2012; and King et al., 2016).

\section{$\mathrm{H}_{2}$ : Education CEO has a positive significant effect on capital expenditure}

\section{Master CEO and Return on Asset}

According to King et al. (2016), Baber and Fabbri (2012) CEOs with MBA education are more aggressive in implementing strategies and tend to speculate. Higher risk is compensated by a higher return. MM-MBA CEOs have higher education, that means the more sophisticated CEO in managing funding and investment decisions (Custodio \& Metzger, 2014) thus can speculate correctly and generate higher returns. Thus the hypothesis is the higher the CEO's education, the higher the CEO's knowledge is to read the conditions and see the emerging opportunities, so as to generate greater profits such as King et al. (2016).

\section{$\mathrm{H}_{3}$ : Education CEO positively affects the return on asset}

\section{Analysis Model}

In this study, there are three analysis models, such as:

$D_{\text {EBT }}$ it $=a+b_{1} E D U_{i t}+b_{2} S I Z E_{i t}+b_{3} A G E_{i t}+\varepsilon$
$C P X_{i t}=a+b_{1} E D U_{i t}+b_{2} S I Z E_{i t}+b_{3} A G E_{i t}+\varepsilon$
$R O A_{i t}=a+b_{1} E D U_{i t}+b_{2} S I Z E_{i t}+b_{3} A G E_{i t}+\varepsilon$

Notes: $a$ is the regression constant; $\beta 1, \beta 2, \beta 3$ are regression coefficient, $D E B T_{i t}$ is total debt ratio per total assets of company $i$ at year $t ; C X_{i t}$ is capital ratio of company $i$ expenditure at year $t ; R O A$ it is return on assets of the company $i$ at year $t$; $E D U$ it is dummy 1 if company $i$ at year thas a CEO with master degree education; $\mathrm{SIZE}_{\text {it }}$ is company size i at year t; $A G E_{\text {it }}$ is the age of the company $i$ since its establishment until the year $t ; \varepsilon$ is error term.

\section{Conceptual Framework}

In this study, there are three research models. The following are three conceptual framework:

CEO Characteristics

\begin{tabular}{|ll|}
\hline Master CEO & $\left(\mathrm{EDU}_{\mathrm{it}}\right)$ \\
\hline Firms Characteristics & \\
\hline Firm Size & $\left(\mathrm{SIZE}_{\mathrm{it}}\right)$ \\
\hline Firm Age & $\left(\mathrm{AGE}_{\mathrm{it}}\right)$ \\
\hline
\end{tabular}

Figure 1. A conceptual framework for model 1 


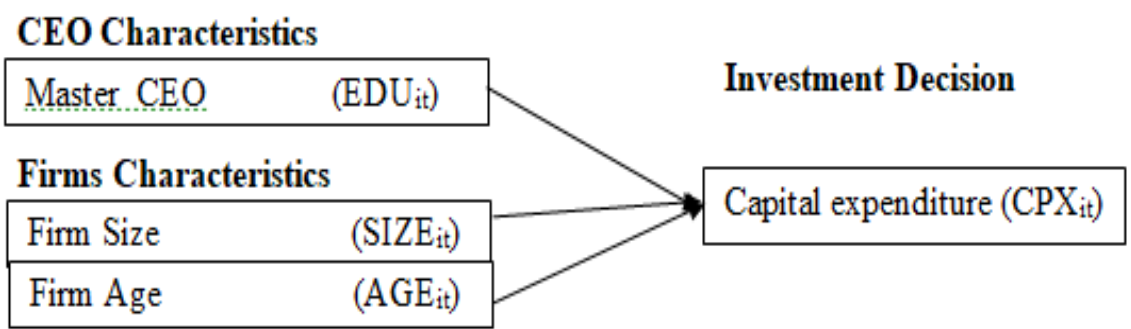

Figure 2. A conceptual framework for model 2

CEO Characteristics

\begin{tabular}{|ll|}
\hline Master CEO & FDU \\
\hline Firms Characteristics & \\
\hline Firm Size & $\left(\mathrm{SIZE}_{\mathrm{it}}\right)$ \\
\hline Firm Age & $\left(\mathrm{AGE}_{\mathrm{it}}\right)$ \\
\hline
\end{tabular}

Figure 3. A conceptual framework for model 3

\section{METHODOLOGY}

This study is a quantitative study on manufacturing-listed companies in Indonesia since 2011 2017. The quantitative approach is done by multiple linear regression. This study has three the dependent variables (funding decision, investment decision, and firm performance), one independent variable (MM-MBA CEO), and two control variables (firm size, firm age). This study used 38 manufacturing-listed companies in Indonesia with total 304 observations. This amount was generated by purposive sampling techniques. This number was reduced due to extreme values which is detected as an outlier by case wise and unavailability of data such as CEO age, so the final observation is 178 observations. Purposive sampling criteria in this study are: registered on the IDX (Indonesia stock exchange) during 2011-2017, audited financial report, Report in same currency IDR (Indonesia Rupiah).

\section{Analysis technique}

The analysis technique used in this study is multiple linear regressions. Regression analysis will explain the effect of independent variables on the dependent variable in the regression equation. The steps taken in this study are:

1. Collect samples of Indonesian manufacturing companies

2. Sorting the sample using a purposive sampling method

3. Classic Assumption Test

4. Multiple Regression Analysis 
In conducting multiple linear regression analysis in this study using the classic assumption test before running that three equations (1),(2),(3). This research use the confidence level (a) of $5 \%$. The acceptance criteria of the hypothesis used are $p$-value $t<a$, then the result is $H_{\circ}$ is rejected, and $\mathrm{H}_{1} \mathrm{OrH}_{2}$ or $\mathrm{H}_{3}$ is accepted.

\section{Operational Definition and Measurement of Variables}

The operational definition of variables for this research, such as:

1. Funding decision in this research is proxied by interest-bearing debt to the total asset. It shows the portion of debt bearing that use for finance total assets.

$\mathrm{DEBT}_{\text {it }}=\frac{\text { interest } \text { bearingdebt }_{\text {it }}}{\text { TotalAsset }_{\text {it }}}$

2. Investment decision in this research is proxied by Capital Expenditure. It shows the portion of new fixed assets and measured by this formula:

CAPEX $_{\text {it }}=\frac{\text { Fixedasset }_{\text {it }}-\text { Fixedasset }_{\text {it }-1}+\text { Depresiasi }_{\text {it }}}{\text { Totalfixedasset }_{\text {it }}}$

3. Firm performance in this research is proxied by Return on Asset. It shows the company's ability to generate a return with total asset and measured by this formula:

$\mathrm{ROA}_{i t}=\frac{\text { EarningsAfterTax }_{\text {it }}}{\text { TotalAsset }_{\text {it }}}$

4. MM-MBA CEO shows that the CEO has a master degree in management and proxied by a dummy variable. It is valued one (1), if CEO has master degree in management (e.g. Master Administration Business or MBA; Master Management or MM) and valued zero (0) if the nation MM or non MBA CEO.

5. Firm size show company's wealth. Size proxied by the natural logarithm of total asset. Firm size $=$ Ln Total assets it

6. Firm age shows how long the company has established until the year $t$ research AGEit $=$ Ln Firm age it

\section{RESULT AND DISSCUSSION}

Table 1 shows the statistic descriptive which includes the value of " $N$ " (number of research observations), the value of "minimum" (the smallest value of all observation), the value of "maximum" (the largest value of all observation), the value of "mean" (average value of all observation), and the standard deviation value data.

Table 1. Descriptive statistics $N$ shows the initial observations were 304 observations. The mean (Std. Deviation) of variables such as interest-bearing debt, capital expenditure, Return on Assets, firm size, and firm age are 0.196 (0.163), 0.222 (0.325), 0.071 (0.088), 0.247 (0.432), 28.366 (1.840), and 3.452 (0.559) respectively. Variable EDU in table 1 shows there are $24.7 \%$ CEO with master degree education in manufacturing-listed companies period 2011- 2017 
Rahmat Setiawan

Lila Gestanti

and the remaining $75.3 \%$ are dominated by non-MM non-MBA CEOs. The data has fulfilled all BLUE assumptions.

Table 2 shows the regression results from all three models. The $\mathrm{F}$ test for the all regression model show all model can explain simultaneously ( $F$ test sig. $0.000<0$. 05). Adjusted $R$ square model $1,2,3$ is $11.7 \%, 18.4 \%$, and $7.5 \%$. That means Model 1, 2, 3 able to explain $11.7 \%$ interest-bearing debt, $18.4 \%$ capital expenditure, $7.5 \%$ return on asset and the remaining 82.3\% interest-bearing debt, $81.6 \%$ capital expenditure, $92.5 \%$ return on the asset are explained by other variables that not examined by the researcher.

Table 1. Statistic descriptive

\begin{tabular}{lccccc}
\hline & $\mathbf{N}$ & Minimum & Maximum & Mean & Std. Deviation \\
\hline DEBT & 304 & 0.000 & 0.592 & 0.196 & 0.163 \\
CPX & 304 & -0.851 & 2.711 & 0.222 & 0.325 \\
ROA & 304 & -0.670 & 0.396 & 0.071 & 0.088 \\
EDU & 304 & 0.000 & 1.000 & 0.247 & 0.432 \\
SIZE & 304 & 24.416 & 33.320 & 28.366 & 1.840 \\
AGE & 304 & 0.000 & 4.159 & 3.452 & 0.559 \\
\hline
\end{tabular}

Source: Data processing using SPSS 20 
Table 2. Regression Results

\begin{tabular}{|c|c|c|c|}
\hline & Interest bearing debt & Capital Expenditure & ROA \\
\hline \multirow[t]{2}{*}{ (Constant) } & $0.561^{* * *}$ & $-0.581^{* * *}$ & $-0.154^{* *}$ \\
\hline & (0.002) & $(0.000)$ & (0.029) \\
\hline \multirow[t]{2}{*}{ EDU } & $-0.134^{* * *}$ & $0.038^{* *}$ & $0.030^{* * *}$ \\
\hline & $(0.000)$ & (0.033) & $(0.005)$ \\
\hline \multirow[t]{2}{*}{ SIZE } & $-0.012^{* *}$ & $0.024^{* * *}$ & $0.006^{* * *}$ \\
\hline & $(0.045)$ & $(0.000)$ & $(0.004)$ \\
\hline \multirow[t]{2}{*}{ AGE } & 0.001 & 0.005 & 0.008 \\
\hline & (0.938) & (0.637) & $(0.260)$ \\
\hline Adj. R square & $11,7 \%$ & $18.4 \%$ & $7.5 \%$ \\
\hline $\mathrm{N}$ & 178 & 178 & 178 \\
\hline Firm & 38 & 38 & 38 \\
\hline F test & 0,000000 & 0,000000 & 0.000881 \\
\hline Note & gnificant 5\% & & \\
\hline Source: Data $p$ & ing using SPSS 20 & & \\
\hline
\end{tabular}

These results show that behavioral theory becomes less relevant in explaining funding behavior of MM-MBA CEOs. MM-MBA CEOs are expected to be overconfidence, because they feel their literation is better than averages, and also motivated by higher compensation (King et al., 2016) so MM-MBA risk tolerance should be higher. These results indicate an agency problem, that MM-MBA tends avoid bonding mechanism from interest-bearing debt usage. Interest-bearing debt usage can reduce agency problem, because this type of debt will bond management to repay the debt by maintaining good performance.

Decision to use lower interest-bearing debt is not fully bad. The advantage is lower interestbearing debt means lower default risk and it can reducing financial costs, even though lost tax savings opportunities and bonding mechanism.

\section{MM-MBA CEOs and Capital expenditure}

Regression results Table 2 shows CEOs with MM and MBA education have a significant positive effect on capital expenditure. These results indicate that companies led by MM-MBA 


\section{Rahmat Setiawan \\ Lila Gestanti}

CEOs have bigger capital expenditure $(3.8 \%)$ than companies led by non MM-non MBA CEOs. This result is consistent with the hypothesis, Barker et al (2002), Beber and Fabbri (2012) and Custódio and Metzger (2014).

This result shows that behavioral finance is still relevant in explaining MM-MBA CEOs behavior in capital expenditure investment decision making. The behavioral theory explained that this characteristic will tend to risk takers, dare to take the risk because this CEOs characteristic with master education have higher cognitive abilities (King et al., 2016), have appropriate knowledge (business) to analyze, understand the benefits of capital expenditure. Furthermore, CEOs with these characteristics have been motivated to take risky decisions, because they have a higher level of compensation (Lam et al., 2014; Graham et al., 2012; King et al., 2016).

Increased in capital expenditure is not always a good decision. There is a possibility CEO might doover investment,empire building, and harm shareholder. The way to prove it is to see the results of regression model 3. It will be an over investment, and harm shareholder, if cant increased profitability and maximize shareholder wealth.

\section{MM-MBA CEOS and ROA}

Table 2. shows that CEOs with MM and MBA education have a significant positive effect on Return On Assets. These results show companies led by MM-MBA CEOs have higher Return On Assets (3\%) than companies led by non MM - non MBA CEOs. These results are consistent with the hypothesis and King et al. (2016).

This result provides information to shareholder and management that MM-MBA CEOs have better performance, so this MM-MBA CEOs characteristic can be considered by the company. This could happen because MM-MBA CEOs have higher education, more sophisticated to make funding and investment decisions (Custódio and Metzger, 2014) thus can produce higher returns.

These results show that Behavior finance theory is relevant enough in explaining MM-MBA CEOs performance. According to Bertrand and Schoar (2003) in King et al. (2016) CEOs with MBA education are more aggressive in implementing strategies and tend to speculate. That high-risk decision compensated by high return. it is true that increasing compensation will reduce profits, but increasing compensation will be a sustainability strategy. high compensation will motivate the CEO and make the CEO more willing to take risks and ultimately increase the company's wealth. Higher education of MM-MBA CEOs helps them to read conditions and see opportunities so that they can generate more profits such as King et al. (2016) result. 


\section{Firm Characteristics and Interest bearing debt}

Table 2 shows firm size has a significantly negative influence on the use of interest bearing debt. It means larger companies will use lower interest bearing debt than smaller companies. The larger companies have already been settled, thus the need to use higher debt has been reduced. It can rely on the company's wealth, the internal fund, or retained earnings.

The next company characteristics is firm age.Firm age does not affect the interest-bearing debt. Older or younger companies will need money for funding their business activity. If company's internal funds are not enough, they will use debt. According to the Pecking Order Theory, company will use the internal funds before use debt. The company will use debt, if the internal source is not enough. The last option to funding the company is by issuing the company's stock. On the other hand, newly established companies may be less credible enough to get a source of debt funds.

\section{Firm Characteristics and capital expenditure}

Results in Table 2 show that firm size has positively affects capital expenditure. This result indicates the larger manufacturing companies have greater new investment in fixed asset (capital expenditure). The larger companies will have greater wealth, so their ability to fund the new fixed asset investments is bigger than smaller companies.

Firm age has no significant effect on capital expenditure. The older or younger company needs he attractive investment opportunities to expand their business. On the other hand, not only the older or younger companies have attractive investment opportunities but also they have no sufficient money to fund this investment opportunity.

\section{Firm Characteristics and Return on Assets}

Results in Table 2 show that firm size positively significant affects ROA. This result shows that the larger the company will make the greater the ROA. Companies with bigger firm size have the economics of scale, thus the companies can decrease their production costs and increase profits. This research's result in accordance with Lam et al. (2013).

Firm age has no significant effect on ROA. The length of the company standing does not affect the value of ROA that is generated by the company. The mean value of firm age in table 1 shows companies in the sample tend to have been standing long. The Longerestablished companies cannot always generate higher ROA. The older companies usually have position in the stage of decline. This position of life cycle indicates that the companies have lower financial performance and need to good corporate governance. 


\section{Research Implications}

The result showed that behavioral theory is still relevant in explaining investment decision for MM-MBA CEOs behavior, but the relevant of this theory is reduced in explaining funding decision for MM-MBA CEOs behavior, but according to the agency theory, there is the possibility of an agency problem due to indications of avoiding the use of interest bearing debt. the usage of interest bearing debt will bind (bonding mechanism) and monitor firm performance. This result shows that MM-MBA CEOs success increase shareholder wealth by increased profitability. It proves that it's not empire building for increased capital expenditure and lower debt usage decrease financial cost and increase profit. These research results provide information to shareholders and management of manufacturing companies to consider and provide equal opportunities to hire MM-MBA CEOs.

\section{Research Limitations}

There are many facts that cannot be limited, thus limiting the results of this study. First, use MM-MBA characteristic, there are possible differences in MM characteristic and MBA characteristics. This done to increase Master in Management sample. Both of these education have the same background, but there are possible differences in the quality of literacy that is owned by the CEO with MM degree and CEO with an MBA degree. Second, this study research only focuses on the manufacturing-listed company, due to reduce industrial variation.

\section{CONCLUSIONS AND SUGGESTIONS}

Based on the research results, it can be concluded MM-MBA CEOs negatively significant affects funding decision (interest-bearing debt to total assets), positively significant affects both investment decision (capital expenditure) and firm performance (Return on Assets). These results indicate that MM-MBA CEOs will reduce interest-bearing debt in accordance with avoiding default risk and bonding mechanism.For further research, it can research other industries other than manufacturing, such as the banking industry.

\section{REFERENCES}

Barker III, V. L., and Mueller, G. C. 2002. CEO characteristics and firm R\&D spending. Management Science, 48(6), 782-801.

Beber, A., and Fabbri, D. 2012. Who times the foreign exchange market? Corporate speculation and CEO characteristics. Journal of Corporate Finance, 18(5), 1065-1087. 
Bhagat, S., Bolton, B., and Subramanian, A. 2010. CEO education, CEO turnover, and firm performance.

Bodie, Z., A. Kane, and A. Marcus. 2010. Investments, 9th ed. Berkshire: McGraw-Hill Education.

Custódio, C., and Metzger, D. 2014. Financial expert CEOs: CEO' s work experience and firm' s financial policies. Journal of Financial Economics, 114 (1), 125-154.

Faccio, M., Marchica, M. T., and Mura, R. 2016. CEO gender, corporate risk-taking, and the efficiency of capital allocation. Journal of Corporate Finance, 39, 193-209.

Frank, M. Z., and Goyal, V. K. 2007. Corporate leverage: How much do managers really matter?.Available at SSRN 971082

Graham, J. R., Li, S., and Qiu, J. 2012. Managerial attributes and executive compensation. The Review of Financial Studies, 25(1), 144-186.

Hackbarth, D. 2008. Managerial traits and capital structure decisions. Journal of Financial and Quantitative Analysis, 43(4), 843-881.

Indonesian Ministry of Industry. 2016. Manufacturing Contribution for Indonesia's GDP. [On line]. From: http://www.kemenperin.go.id/artikel/18611/Kontribusi-Manufaktur-RITertinggi-di-ASEAN. [June 28, 2018].

King, T., Srivastav, A., and Williams, J. 2016. What's in an education? Implications of CEO education for bank performance. Journal of Corporate Finance, 37, 287-308.

Korkeamäki, T., Liljeblom, E., and Pasternack, D. 2017. CEO power and matching leverage preferences. Journal of Corporate Finance, 45, 19-30.

Lam, K. C., McGuinness, P. B., and Vieito, J. P. 2013. CEO gender, executive compensation and firm performance in Chinese-listed enterprises. Pacific-Basin Finance Journal, 21 (1), 1136-1159.

Nguyen, D. D., Hagendorff, J., and Eshraghi, A. 2015. Which executive characteristics create value in banking? Evidence from appointment announcements. Corporate Governance: An International Review, 23(2), 112-128.

Ross, S.A., Westerfield, R.W., and Jaffe, J. 2010. Corporate Finance. McGraw-Hill 
Rahmat Setiawan

Lila Gestanti

Rossi, F., Hu, C., and Foley, M. 2017. Women in the boardroom and corporate decisions of Italian listed companies: Does the "critical mass" matter? .Management Decision, 55 (7), 1578-1595. 